Ruth A. Burch

\title{
ON JEAN-JACQUES ROUSSEAU'S IDEAL OF NATURAL EDUCATION
}

\begin{abstract}
The aim of this contribution is to critically explore the understanding, the goals and the meaning of education in the philosophy of education by Jean-Jacques Rousseau. In his educational novel Emile: or On Education [Emile ou De l'éducation] (1762) he depicts his account of the natural education. Rousseau argues that all humans share one and the same development process which is independent of their social background. He regards education as an active process of perfection which is curiosity-driven and intrinsic to each child. Rousseau's educational goals are autarky, happiness and freedom.

Keywords: Jean-Jacques Rousseau; education; natural man; nature; culture; science, voice of conscience; freedom; equality.

The aim of this contribution is to critically explore the understanding, the goals, and the meaning of education in the philosophy of education by JeanJacques Rousseau (1712-1778). Rousseau is a Swiss-French philosopher and political theorist from Geneva who was a member of Diderot's circle and one of the great figures of the French Enlightenment. Further, he has also had a decisive influence on 19th century Romanticism and its focus on subjectivity and the primacy of the individual over society.
\end{abstract}

\section{NATURAL MAN}

In his educational novel Emile: or On Education [Emile ou De l'éducation] (1762), which is Rousseau's longest and most detailed book, he develops his philosophy of education. His ideal of natural education represents one way of becoming an autonomous and responsible human. Yet there is a basic contradiction in this didactic novel between the demand for a "natural" development and an educational manual with hundreds of pages of instructions for human inter- 
vention into the process of growing up. The main reason, why Emile Rousseau's longest book is, is that the work addresses in detail fundamental political and philosophical questions about the relationship between the individual and society. The author's principal concern is to find an answer to the question: how might the individual retain its innate human goodness while remaining part of a corrupting collectivity that produces deformity and monstrosity at its stead? The book's famous opening line sets the stage for this undertaking:

"everything is good as it leaves the hands of the Author (creator) of things (that is, god); everything degenerates in the hands of man." ${ }^{1}$ Peter Jimack comments that Emile attempts to "find a way of resolving the contradictions between the natural man who is 'all for himself' and the implications of life in society.",

Rousseau regards his Emile as his most important book. I use Allan Bloom's English translation of it as it accurately renders Rousseau's outstanding mastery of the French language and his precise and careful writing style which is both philosophical and literary. Bloom calls Rousseau's pedagogic work correctly a "most fundamental and necessary book" ( $E$, vii). I also agree with him to not regard it as an educational manual, but rather as a book that adopts the convention of rearing a boy (and a girl) in order to "survey the entire human condition" $(E, 28)$. In the negative pedagogy presented in it Rousseau prefers with regard to the up-bringing of children non-interference over interference. For the Rousseauian educator, developing the self of the noble savage happens through a greater extent by means of laisser faire than through active intervention. In education "laissez-faire" means a style of education which lets the child do what it likes; education is seen as an illegitimate action against children, correspondingly targeted educational measures are omitted in the teacher-studentrelation. In his book Emile Rousseau develops the concept of a natural education. According to it, man is inherently good. Yet his innate capacities can develop to their best or alternatively destroy him. $(E, 214)$ In his view, an erroneous development is, hence, attributable to detrimental social influences. Thereby Rousseau assumes that socialized life tends or even compels humans to compare themselves with their peers and in this way the generation of the destructive passions comes about. He opposes in particular educators who exploit passions such as rivalry "emulation, jealousy, envy, vanity, avidity and vile fear" $(E, 92)$ for educational ends. Given that he entertained little hope that such vices can be eradicated, in order to ensure a healthy development of the child, he saw the task of education in shielding children against these undesirable influences.

\footnotetext{
${ }^{1}$ Rousseau, J.-J. 1762/3. Emile: or On Education. Bloom, A. (Trans.). New York: Basic Books, 1979, 37 [henceforth cited as $E$ ].

2 Jimack, P. 1983. Rousseau: Émile. London: Grant and Cutler, Ltd., 33.
} 
He, thus, states that "the first education must therefore be purely negative. You must not instruct the child in virtue and truth, but must keep its heart from vice and the mind from error." Rousseau suppresses the early growth of the passions, particularly fear of death and amour-propre ( $E$, I 9). He does not want them to transform judgment propelled by imagination and the admixture of the senses and the desires. In contrast to this, for Rousseau, self-love (amour de soi), is the basic innate and, hence, natural passion. It is its alienating, harmful modifications that he opposes for they alter man so that, as Rousseau writes, he "finds himself outside of nature and sets himself in contradiction with himself" ( $E$, 212-3). Natural man is good and happy and his self-love is the source of his gentle and affectionate passions. In contrast to this, for instance, amour-propre is not referring to oneself, but it refers to others and wants to force them to love the person in question more than they love themselves which, staying within Rousseau's model of the self, is impossible and this gives rise to hate and anger (E, 213-4).

In the second phase of the educational process occurs a change in the selfawareness of the pupil. The main goal of the formation up to this point had been to understand oneself better by way of understanding better one's relation to the object world. Learning from experience is the objective and verbal lessons are not conducive to that. Rousseau writes that

"the study suitable for man is that of his relations. So long as he knows himself only in his physical being, he ought to study himself in his relations with things. This is the job of his childhood. When he begins to sense his moral being, he ought to study himself in his relations with men" $(E, 214)$.

In Rousseau, the active positive engagement with the structures of civilization such as the invention of private property, the division of labor, the contention with morals and beliefs is only sought once the formation of judgment on physical phenomena is completed and Emile accompanied by his tutor and mentor enters society. Thereby "negative education" creates protected spaces and enables the formation of judgment independent of social influences. The opening of the preface of the book forms a Latin citation from Seneca's De ira [Of Anger] which reads: "we are sick with evils that can be cured; and nature, having brought us forth sound, itself helps us if we wish to be improved." 3 ) According to Rousseau's psychological insight, a great part of the social problems is indeed caused by anger. For this reason, according to him, it needs to be overcome. Natural man is whole and simply concerned with himself. His first care is self-preservation. Rousseau introduces into education the idea of authen-

\footnotetext{
${ }^{3}$ Sanabilibus aegrotamus malis; ipsaque nos in rectum genitos natura, si emendari velimus, invat. From Seneca. 2007. De ira. Stuttgart: Philipp Reclam jun, B II, 13.
} 
ticity, of staying true to oneself. Emile is the opposite of the inauthentic bourgeois. He upholds egalitarian principles.

In his education lectures, Immanuel Kant, who was a contemporary of Rousseau, has taken up the term and concept of "negative education." He writes: "incidentally, I did not know what in education and especially in early education, would be more necessary and important than negative education, namely of both a prohibitive and inhibitive quality." As educational utopia negative education has a long tradition. From Plato's State, to Goethe's "pedagogical province" in the Wilhelm Meister to the "educational islands" in the 20th century's progressive education, the idea has been repeatedly revived, often under the name of "non-education."

Negative education is pedagogy of preservation. It aims to preserve the child from an early exposure to bad influences. In Rousseau's view, one such bad influence is the reading of books. He regards the early reading of books as the "scourge of childhood." Rousseau contributed with his Emile significantly to considering childhood as a stage in life that is qualitatively different from that of being an adult. ${ }^{5}$ In the Preface to the Emile he simply states: "childhood is unknown." That is why he wants to explore "what $[\ldots]$ man is before being a man" (E, P 33).

A natural education is one that "consists not in teaching the child many things, but never letting anything but accurate and clear ideas enter his brain." Rousseau, in his longing to return to the state of nature, ventures to raise a natural man. Emile or: On Education is the corner stone to Rousseau's Discourse on the Sciences and Arts and to his Discourse on the Origin and Foundations of Inequality. Rousseau's imaginary pupil, Emile, will get his lessons from nature and not from men. He writes: "I want him to learn in detail, not from books but from things" $(E, 185)$. Rousseau is not concerned with teaching Emile numerous facts, but with instructing the child to be able to think for himself, to make his own experiences and to learn from them. Emile will have one mentor, Robinson Crusoe (1719). Crusoe is Rousseau's modern natural man. Rousseau explains that Crusoe is "on his island, alone, deprived of the assistance of his kind and the instruments of all the arts, providing nevertheless for his subsistence" $(E, 184)$.

Rousseau goes to extremes to create a childhood that is free from habit, and one that provides Emile with the greatest adaptability to his surroundings, whatever they may be, for the rest of his life. His tutor loathes all books and above all the Bible. He gives Emile Robinson Crusoe towards the end of the third book, prior to his early adulthood or adolescence $(E, 184-5)$. He wants his pupil

${ }^{4}$ Kant, I. 1800. Sammlung einiger bisher unbekannt gebliebener kleiner Schriften von Immanuel Kant [Collection of Some Hitherto Unknown Smaller Writings]. Rink, F. T. (Ed.). Königsberg: Fr. Nicolovius, 58-63, here p. 61 (the author's own translation).

5 See, for instance, Holmsten, G. 1972. Jean-Jacques Rousseau in Selbstzeugnissen und Bilddokumenten. Reinbek (Hamburg): Rowohlt, 107. 
to understand on his own rather than just adopting views of others expressed in books. I endorse Bloom's view that Rousseau gives Emile this book not for pure enjoyment, but in order "to provide him with a vision of the whole and a standard for the judgment of both things and men" $(E, I 7)$. Robinson Crusoe is a solitary man in the state of nature, outside of civil society and unaffected by the deeds or opinions of men. His sole concern is his preservation and comfort. All his strength and reason are dedicated to these ends, and utility is his guiding principle, the principle that organizes all of his knowledge. The world he sees contains neither gods nor heroes; there are no conventions. Neither the memory of Eden nor the hope of salvation affects his judgment. Nature and natural needs are all that is of concern to him. The Life and Strange Surprising Adventures of Robinson Crusoe is a kind of bible of the new science of nature and reveals man's true original condition ( $E, \mathrm{I} 7)$.

\section{A FEW REMARKS ABOUT EACH OF THE FIVE BOOKS}

Rousseau shows the psychological development of an imaginary pupil through the different stages of his childhood and adolescence. These stages are divided into five distinctive phases to which correspond the five books that are contained within the book. In the "Introduction" Rousseau confirms that the systematic part of his treaty follows the course or "the march of nature" $(E, \mathrm{P}$ 34).

Rousseau's conviction that human development follows certain unchanging principles implies that the child is being corrupted when its educator is going against these natural laws of development. The educator needs, thus, to be knowledgeable in what Rousseau calls "the art of forming man" $(E, \mathrm{P} 33){ }^{6}$ Emile is divided into two large segments. Books I-III are devoted to the rearing of a civilized savage, a man who cares only about himself, who is independent and self-sufficient and on whom no duties that run counter to his inclinations and so divide him are imposed, whose knowledge of the crafts and the sciences does not involve his incorporation into the system of public opinion and division of labor. Yet books IV-V attempt to bring this isolated individual into human society and into a condition of moral responsibility on the basis of his inclinations and his generosity $(E, \mathrm{I} 7)$.

As mentioned above, the text is divided into five books: the first three are dedicated to the child Emile, the fourth to an exploration of the adolescent, and the fifth to outlining the education of his female counterpart Sophie, as well as to Emile's domestic and civic life. In the first book, Rousseau discusses not only his fundamental philosophy but also begins to outline how one would have

\footnotetext{
${ }^{6}$ Later drew Pestalozzi among others on Rousseau's concept of "the course of nature" for expressing his own pedagogic ideas.
} 
to raise a child to conform to that philosophy. He begins with the early physical and emotional development of the infant and the child. The second book concerns the initial interactions of the child with the world. Rousseau believed that in this phase education should be derived less from books and more from the child's interactions with the world, with an emphasis on developing the senses, and the ability to draw inferences from them. The third book is concerned with the selection of a trade, for Rousseau believed it necessary that the child must be taught a manual skill appropriate to his gender and age, and suitable to his inclinations, by worthy role models $(E, 20-27)$.

Next, I treat book four. Once Emile is physically strong and learns to carefully observe the world around him, he is ready for the last part of his education-sentiment: "We have made an active and thinking being. It remains for us, in order to complete the man, only to make a loving and feeling being - that is to say, to perfect reason by sentiment" ( $E$ 203). Emile is a teenager at this point and it is only now that Rousseau believes he is capable of understanding complex human emotions, particularly empathy and pity. Rousseau argues that the child cannot yet put himself in the place of others but once adolescence has been reached and Emile is able to have feelings of compassion, he can finally be brought into the world and be socialized $(E, 222)$.

In addition to introducing a newly passionate Emile to society during his adolescent years, the tutor also introduces him to religion. According to Rousseau, children cannot understand abstract concepts such as the soul before the age of about fifteen or sixteen. Consequently, in order to introduce religion to them is dangerous. He writes: "It is a lesser evil to be unaware of the divinity than to offend it" $(E, 259)$. Moreover, as children are incapable of understanding the difficult concepts that are part of religion, he points out that children will only recite what is told to them - they are unable to believe. Yet, for Rousseau, the joy that existence affords and the good conscience are fundamental for man as he has him in mind.

Due to a section of the book entitled "Profession of Faith of the Savoyard Vicar," Emile was banned in Paris and Geneva and was publicly burned in 1762, the year of its first publication. In the section in question in the fourth part of the book a priest pleads, in Rousseau's name, for a natural religion according to which God speaks directly to the heart of the individual $(E, 266)$. It is a religion of conscience that is universally discernible by all men through the use of human reason independent of any special revelation. According to this section's pantheistic doctrine nature in itself is divine. Rousseau's contemporary and philosophical rival Voltaire was critical of Emile as a whole, but admired the section in the book which had led to it being banned. He remarks about it: "forty pages against Christianity, among the boldest ever known."7

${ }^{7}$ Durant, W. 1967. "Rousseau and Revolution." In: The Story of Civilization, vol. 10. New York: Simon and Schuster, 190-191. 
In book five, Rousseau turns to the education of Sophie, Emile's wife-to-be. Rousseau begins his description of Sophie, the ideal woman, by describing the differences between men and women in a famous passage:

"In what they have in common, they are equal. Where they differ, they are not comparable. A perfect woman and a perfect man ought not to resemble each other in mind any more than in looks, and perfection is not susceptible of more or less. In the union of the sexes each contributes equally to the common aim, but not in the same way. From this diversity arises the first assignable difference in the moral relations of the two sexes" $(E, 358)$. For Rousseau, "everything man and woman have in common belongs to the species, and ... everything which distinguishes them belongs to the sex." Rousseau states that women should be "passive and weak," "put up little resistance" and are "made specially to please man"; he adds, however, that "man ought to please her in turn," and he explains the dominance of man as a function of "the sole fact of his strength," that is, as a strictly "natural" law, prior to the introduction of "the law of love."

Rousseau also touches on the political upbringing of Emile in book $\mathrm{V}$ by including a concise version of his Social Contract into the book. His political treatise The Social Contract was published in the same year as Emile and begins with the widely cited words: "man was born free, and everywhere he is in chains." It was likewise soon banned by the government for its controversial theories on general will. Interestingly, the coexistence of the two separate modes of thinking and of being does not bring about a split man, "un homme double" as in Rousseau's perspective the conflict of natural and social existence does. The treaty ends with matrimony, the prospect of having a family and the birth of a child.

\section{CRITICISM AND CONCLUSION}

According to the above depiction Rousseau wants to go back to nature, to the true self of natural man that became distorted by society, that is, by the demands of social life. To Rousseau's mind, culture and society are not improving man, but rather they are corrupting him. Man is good by nature; it is only civilization and its institutions that influence him in a negative way and turn him bad. The intellectuals of Rousseau's time (the Age of Enlightenment) felt provoked by Rousseau's claim that the progress of science is not worth striving for.

In Rousseau's art of education man is getting educated in three ways: first through nature, second through things and third through human beings. "Natural" man suffices himself. All bad things are man-made. Natural man, thus, prefers his own company over that by the others; he likes to be solitary. On grounds of his peaceful nature he seeks to avoid conflict and feels compassion 
for his fellow men. Rousseau argues that when men live together competition and an excessive narcissism (self-love) arise and men become distrustful and begrudging. Whereas in Rousseau culture and science are corrupt and alienate the homme de la nature from himself, innocent nature is good and represents wisdom and reason. For Rousseau, this is why we should follow the inner voice of conscience, return to nature, and focus on the natural state and the natural right which grants freedom and equality to all men.

Johann Wolfgang von Goethe wrote in 1787 that "Emile and its sentiments had a universal influence on the cultivated mind. ${ }^{8}$ Rousseau seeks to describe a system of education that would enable the natural man he identifies in The Social Contract (1762) to survive corrupt society. Rousseau does not want to overburden the child and to swamp it with knowledge for which its nature is not ready yet. His concept of negative education cannot be construed as a form of anti-pedagogy, because Rousseau's educator has to perform a lot of tasks throughout. Rousseau withholds to youngsters access to books and poetry. I disagree with this practice because it seems to me that he deprives children of important sources of joy and learning, especially children with artistic talents or sensibilities will suffer from such tutelage. But also linguistic learning is impeded when the imagination is not fed. Besides, he is against advocating lying to children, for they normally perceive dishonesty as such often without being able to put this into words. Lies are always harmful to them as they, once uncovered as such, diminish their trust into the world. Yet Rousseau's tutors use artifice and trickery in order to execute negative education. This means their tutoring too relies in part on insincerity.

According to my own practical observations the theoretical emancipation process occurring in traditional classrooms is often thwarted by way of a practical education that fosters and rewards immaturity and submission. An example for this is, in my view, the excessive testing that is done in schools which has the effect that students are exclusively concentrating on passing the next exam and teachers on preparing them for it. In such a context learner autonomy often only means that the students have to do a lot of homework instead of being given the space to work on individual projects on topics that are relevant to the individual students' life and interests and therefore would have the power to draw on their inherent motivational forces. When the parents and/or the teachers of a child or youngster are his friend (rather than their pupil) I find this an abusive relationship for in such a relational constellation the child has more power and responsibility than it can cope with.

Rousseau advocates a life of rural simplicity. I find the idea of going back to nature worthy of support when by it is meant co-evolution and being in tune with one's surroundings. But I think that Donna Haraway is right when she says in her Cyborg Manifesto from 1985 and elsewhere that nature and culture are

\footnotetext{
${ }^{8}$ Ibid., 889.
} 
inseparable. Rather, according to her, they are mere fictional oppositions. It is, therefore, no option for us wanting to go back to some kind of natural state.

Next, I criticize Rousseau for another dichotomy on which his work rests, namely the opposition of reason and love. For him reason judges objectively and love chooses in an irrational manner. ${ }^{10}$ Yet I endorse his idea of lovepassion in marriage. Rousseau educates first Emil's reason before he educates his sentiment through the introduction of a woman, Sophie. He clearly associates man with reason and woman with love which in this manner becomes essentially the lack of reason. I disagree fundamentally with Rousseau's division of emotion from reason and consequently also with his allocation of reason to men and of emotion to women. Rather I think that the rational and the emotive are inseparable and, thus, stand in a relation of mutual dependency to each other.

Regarding the sexualized formation of Sophie I disapprove of the fact that there are no good reasons provided by Rousseau that would be sufficiently convincing for treating women differently. Rousseau has had a very harmful influence on women's condition to this day through his reinforcement of a reactionary and paternalistic treatment of women. In regard to women there is clearly violence and oppression present in the otherwise anti-violent Rousseau. Women are made to subject themselves to their husbands and at the same time they are being made responsible that men behave (morally) in the correct way. The love to a woman gives a man the readiness to "denature" himself and to become a citizen. This means social life is only possible because of woman. The restriction of citizenship to males is completely inacceptable. ${ }^{11}$ This is even so within Rousseau's own framework, for he rejects personal dependence and demands moral and political autonomy. In sum, in the apprenticeship to life Rousseau's educator is providing to women, he goes in a crass way against his own egalitarian principles. When Rousseau invokes Emile's "second birth" in puberty, which amounts to self-birthing, that is, the giving of birth to a second female self capable of love in addition to his male self of reason, he is appropriating both the metaphor and the reality of giving birth from women.

The development of the capacity to be alone is vital for a life in happiness, especially for girls who by trend today still are instructed as a priority to enter relationships and thus to establish dependencies from others. In my view, the capacity for aloneness is the precondition, indifferent of sex, to enter fruitful relationships with others.

\footnotetext{
${ }^{9}$ Haraway, D. 1985. "A Manifesto for Cyborgs: Science, Technology, and Socialist-Feminism in the Late Twentieth Century." In: Simians, Cyborgs, and Women: The Reinvention of Nature. Haraway, D. (Ed.). New York: Routledge, 149-181.

${ }^{10}$ See Derrida, J. 1967. Of Grammatology. Baltimore: Johns Hopkins University Press.

${ }^{11}$ See Canovan, M. 1987. "Rousseau's Two Concepts of Citizenship." In: Women in Western Political Philosophy: Kant to Nietzsche. Kennedy, E., S. Mendus (Eds.). New York: St. Martin's Press, 78-105.
} 
The fourth book in Emile is concerned with the religious dimension in humans. We have seen above that Rousseau thinks that only adolescents are capable of understanding philosophical and theological abstractions. But more importantly, the child needs no religion as this allows it to grow up without internal conflicts in happy mental autarky. Last, but not least, I am in support of Rousseau's idea that children should not be exposed to religious beliefs before puberty for otherwise this means to exert violence on children, as for instance Richard Dawkins in a clear and succinct mode has argued in The God Delusion (2006). Children have to be given a chance to realize that also as an atheist one can lead a happy, balanced, moral, and intellectually fulfilled life.

ABOUT THE AUTHOR - PhD, an independent scholar and translator. She is the Assistant Editor of the open-access Journal Existenz (www.existenz.us) and the Secretary of the Karl Jaspers Society of North America (KJSNA). She was awarded her PhD in Philosophy from Warwick University in 2009 for her thesis "Is Donna Haraway's 'Situated Knowledge' Nietzschean 'Gay Science'?"

E-mail: burchru@hotmail.com 